\title{
ASPEK NORMATIF ASAS KONSENSUALISME DALAM PENAMBAHAN KLAUSULA KONTRAK TANPA PERSETUJUAN PARA PIHAK
}

\author{
Siti Nurwullan \\ Hendrik Fasco Siregar \\ Fakultas Hukum, Universitas Pamulang \\ Email : wulancitra228@gmail.com
}

Received: Mar 2019/Revised: Mar 2019/Accepted: Ags 2019

\begin{abstract}
Kejujuran merupakan prinsip dasar dari asas itikad baik dalam kontrak/perjanjian. Itikad baik para pihak pembuat kontrak berkaitan dengan sikap batin para pembuat kontrak. Kejujuran merupakan unsur yang utama dalam pembuatan perjanjian/ kontrak karena ketidakjujuran salah satu pihak dalam perjanjian/ kontrak dapat mengakibatkan kerugian bagi pihak lainnya, baik itu karena tidak dapat dilanjutkannya kontrak maupun karena diputusnya kontrak secara sepihak. Kejujuran para pihak dalam kontrak meliputi pada kejujuran atas asal usul identitas diri dan kejujuran atas kehendak serta tujuan para pihak. Berkontrak dengan itikad baik adalah melaksanakan perjanjian dengan mengikuti atau mentaati norma-norma kepatutan dan kesusilaan. Kewajiban untuk melaksanakan kontrak berdasarkan itikad baik, asas itikad baik (good faith) merupakan salah satu sendi terpenting dalam hukum perjanjian, yang akan menjawab pertanyaan apakah yang bersangkutan menyadari atau tahu, bahwa tindakannya bertentangan dengan itikad baik.
\end{abstract}

Kata Kunci : Kontrak, Itikad baik, kejujuran, klausula, sikap batin

\section{ABSTRACT}

Honesty is a basic principle of good faith principles in contracts / agreements. The good faith of the treaty parties is related to the inner attitude of the agreement makers. Honesty is the main element in making agreements / contracts because dishonesty of one of the parties in the agreement / contract can cause harm to the other party, either because the contract cannot be continued or because the contract is unilaterally terminated. Honesty of the parties in the agreement includes honesty of self-identity and honesty at the will and purpose of the parties. Contracting in good faith is implementing an agreement by following or adhering to the norms of decency and decency. The obligation to carry out contracts based on good faith, good faith is one of the most important joints in the treaty law, which will answer the question whether the person concerned is aware or knows, that his actions are contrary to good faith. Factual when the parties have agreed to the contract material and when the contract will be signed by the parties it turns out that one party unilaterally adds the clause in the agreement without the other party's 
knowledge and approval, while in the field It turns out that the main contract has been carried out by one party who objected to the addition of the clause and the party that has carried out the contents of the contract has objected to the addition of the clause, which in the end the party who made the clause in bad faith unilaterally broke the contract without the agreement of another party, this certainly harmed the other parties both material and moral who had carried out the contract in faith well.

Keywords: Contract, Good faith, honesty, clause, inner attitude

\section{PENDAHULUAN}

Asas Pacta Sunt Servanda telah meletakan posisi kontrak yang dibuat oleh masyarakat menjadi undang-undang baginya. Semua perjanjian/kontrak yang dibuat secara sah berlaku sebagai undang undang bagi mereka yang membuatnya dan kontrak tersebut tidak dapat ditarik kembali selain dengan kesepakatan para pihak atau karena alasan-alasan yang telah ditetapkan oleh undang-undang. Dalam Asas Pacta Sunt Servanda terkandung makna suatu kontrak harus dilakukan dengan sikap batin yang dimanepestasikan dalam bentuk itikat baik pembuatnya, dan menurut hemat penulis suatu hal yang penting yang patut diperhatikan dalam suatu perjanjian tidak hanya mengikat untuk hal-hal yang dengan tegas dinyatakan didalamnya, tetapi juga untuk segala sesuatu yang menurut sifat dari suatu kontrak yang diharuskan oleh kepatutan, kebiasaan atau undang-undang.

Pada aspek materiil kebebasan berkontrak bukanlah kebebasan yang tak terbatas, karena tetap ada batasannya dan akan ada akibat hukum yang timbul terhadap kebebasan yang tak terbatas itu, secara limitative batasbatas kebebasan berkontrak, yaitu bila suatu kontrak melanggar peraturan perundang-undangan atau suatu public policy dan nilai-nilai moralitas atau etika dalam masyarakat, maka kontrak tersebut menjadi illegal. Pasal 1338 KUHPerdata, yang menyatakan bahwa "semua kontrak yang dibuat secara sah akan mengikat sebagai undang undang bagi para pihak dalam kontrak tersebut". Subsatansi dari pasal 1338 KUHPerdata yaitu itikad baik para pihak yang tertuang dalam klusula pada perjanjian/kontrak tidak sematamata terbatas pada apa yang diperjanjikan, akan tetapi juga terhadap beberapa unsur penting lainnya lain sepanjang dikehendaki oleh kebiasaan dan kepatutan secara moral.

Faktual dalam kehidupan bisnis dan perdata sehari-hari berkontrak dapat terjadi ketika para pihak telah setuju dengan materi kontrak yang tertuang dalam klausula serta siap untuk menundukkan diri pada klausula perjanjian yang telah disepakati, tetapi ketika kontrak akan ditandatangani 
ternyata salah satu pihak menambah klausula dalam perjanjian, dan dilain pihak dilapangan ternyata kontrak utama telah dijalankan oleh salah satu pihak yang merasa keberatan adanya penambahan klusula tersebut, sehingga pihak yang telah melaksanakan isi kontrak keberatan adanya penambahan klausula yang pada akhirnya pihak yang merasa memiliki kekuasaan sebagai "Pemegang tender" memutuskan kontrak tanpa persetujun pihak "Pemenang tender", pemutusan kontrak secara sepihak apalagi kontrak telah dilaksanakan oleh "pemenang tender" tentu akan merugikan pihak yang telah melaksanakan kontrak secara materiil dan moraiil.

\section{PERMASALAHAN}

Berdasarkan latar belakang yang diuraikan di atas, maka penulis merumuskan masalah sebagai berikut :

I. Apakah akibat hukum kontrak bagi para pihak dengan penambahan klausula tanpa disetujui salah satu pihak?

2. Bagaimana hubungan asas itikad baik dalam berkontrak dengan pemutusan kontrak secara sepihak?

\section{METODOLOGI PENELITIAN}

Metode penelitian yang digunakan meliputi kepustakaan; pengamatan (observasi), wawancara (interview). Sesuai dengan sumber data seperti yang dijelaskan di atas, maka dalam penelitian ini pengumpulan data dilakukan dengan cara Studi Kepustakaan Terhadap data sekunder dikumpulkan dengan melakukan studi kepustakaan, yaitu dengan mencari dan mengumpulkan serta mengkaji peraturan perundang-undangan, rancangan undang-undang, hasil penelitian, jurnal ilmiah, artikel ilmiah, dan makalah seminar yang berhubungan dengan Kontrak/Perjanjian.

Metode analisa data yang digunakan dengan cara data yang diperoleh baik dari studi kepustakaan maupun dari penelitian lapangan akan dianalisis secara deskriptif kualitatif. Analisis deskriptif kualitatif yaitu metode analisis data yang mengelompokkan dan menyeleksi data yang diperoleh dari penelitian lapangan menurut kualitas dan kebenarannya, kemudian dihubungkan dengan teori-teori, asas-asas, dan kaidah-kaidah hukum yang diperoleh dari studi kepustakaan sehingga diperoleh jawaban atas permasalahan yang dirumuskan. 


\section{PEMBAHASAN}

\section{Berkontrak sebagai awal Kerjasama berlandaskan kejujuran.}

Secara substansial berkontrak dapat diartikan sebagai peristiwa di mana seseorang atau lebih berjanji kepada orang lain di mana dua orang saling berjanji untuk melaksanakan sesuatu dengan itikad baik, lebih konkrit berkontrak atau membuat perjanjian merupakan satu atau serangkaian janji yang dibuat para pihak dan esensi dari kontrak itu sendiri adalah perjanjian (agreement) dengan itikad baik. Janji atau berjanji itu sendiri menurut hemat penulis merupakan pernyataan yang dibuat oleh seseorang kepada orang lain dengan itikad baik yang menyatakan suatu keadaan tertentu atau affair exists untuk melakukan suatu perbuatan tertentu atau tidak melakukan perbuatan tertentu, dan pada akhirnya para pihak akan terikat pada janjinya sendiri yang telah dituangkan dalam klausula kesepakatan bersama, dimana janji yang diberikan kepada pihak lain dalam perjanjian bersifat mengikat dan janji menimbulkan kewajiban yang harus dipenuhi.

Dalam berbagai definisi yuridis konvensional secara esensial kontrak itu berisi serangkaian janji-janji, tetapi yang dimaksud dengan janji itu secara tegas dinyatakan adalah janji yang memiliki akibat hukum dan apabila dilanggar maka nantinya pemenuhannya dapat dituntut ke pengadilan atau dengaan kata lain kontrak ini bertujuan untuk menciptakan akibat hukum untuk kepentingan satu pihak dan juga untuk pihak lain. Pasal 1313 KUHPerdata mendefinisikan perjanjian sebagai suatu perbuatan yang terjadi antara satu atau dua orang atau lebih mengikatkan dirinya terhadap orang lain. Menurut penulis Pengertian kontrak ini memiliki dua dimensi yaitu merupakan suatu perbuatan hukum (juridical act), yang dibuat dengan formalitas yang akan disepakati, dan disahkan oleh hukum yang berwenang-serta dibuat bersesuaian, dan harus ada ungkapan niat dari satu atau dua pihak secara bersama-sama yang saling bergantung satu sama lain(interdependent).

Aspek ketergantungan satu sama lain (interdependent) menegaskan bahwa berkontrak adalah merupakan perbuatan hukum, perbuatan hukum yang dimaksud adalah suatu perbuatan yang menghasilkan akibat hukum dikarenakan adanya niat dari perbuatan satu orang atau lebih. Kesepakatan bersama (mutual consent) dengan itikad baik para pihak merupakan ciri khas yang paling subtantif dari suatu kontrak. Kesepakatan bersama ini bukan hanya merupakan karakteristik dalam pembuatan kontrak, tetapi hal itu penting sebagai suatu niat yang diungkapkan kepada pihak lain dengan itikad baik. 
Pada Akhirnya kata sepakat adalah pertemuan atau persesuaian kehendak baik antara para pihak di dalam perjanjian berupa Niat baik (itikad baik) para pihak dan harus bertujuan untuk menciptakan adanya akibat hukum. J.Satrio dalam Bukunya Hukum perikatan merumuskan itikad baik secara tersirat dalam perjanjian sebagai "Seseorang dikatakan memberikan persetujuannya atau kesepakatannya jika ia memang

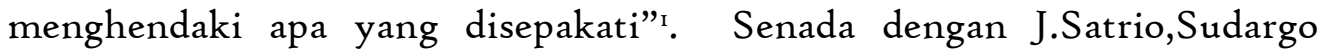
Gautama menegaskan, "Supaya kontrak menjadi sah maka para pihak harus sepakat terhadap segala hal yang terdapat di dalam perjanjian". Mariam Darus Badrul zaman melukiskan pengertian sepakat sebagai persyaratan kehendak yang disetujui (overeenstemende wilsverklaring) antara pihak-pihak. Pernyataan pihak yang menawarkan dinamakan tawaran (offerte). Dan pernyataan pihak yang menerima penawaran dinamakan akseptasi (acceptatie) ${ }^{3}$. Dengan demikian menurut hemat penulis kata sepakat yang dituangkan dalam klausula perjanjian dapat diungkapkan para pihak dengan dalam berbagai cara, yaitu Secara lisan dengan kontak secara lngsung, Tertulis dengan tanda yang dimengerti para pihak, Dengan symbol yang telah dipahami, Dengan diam-diam menundukkan diri pada klausula yang telah disepakati, dan dengan tindakan nyata secara langsung.

Secara yuridis konvensional terdapat empat persyaratan yuridis agar suatu kontrak dianggap sah yitu meliputi Syarat sah yang obyektif berdasarkan pasal $1320 \mathrm{KUH}$ Perdata Objek / terkait perihal tertentu, terkait kausa yang diperbolehkan / dihalalkan / dilegalkan, dan terkait syarat sah yang subjektif berdasarkan pasal 1320 KUH Perdata yaitu adanya kesepakatan dan kehendak Wenang berbuat.

Terhadap syarat sah yang umum di luar pasal $1320 \mathrm{KUH}$ Perdata ternyata terdapat syarat bahwa kontrak harus dilakukan dengan I'tikad baik, Kontrak tidak boleh bertentangan dengan kebiasaan yang berlaku, Kontrak harus dilakukan berdasarkan asas kepatutan, Kontrak tidak boleh melanggar kepentingan umum. Bahkan lebih konkrit terhadap syarat sah yang khusus yaitu ada syarat tertulis untuk kontrak-kontrak tertentu dan syarat akta notaris serta syarat akta pejabat tertentu (selain notaris) untuk kontrak-kontrak tertentu, serta adapula syarat izin dari pejabat yang berwenang untuk kontrak-kontrak tertentu.

\footnotetext{
1J. Satrio,Hukum Perikatan,Perikatan yang lahir dari Perjanjian,Bandung, 1995,hlm.76.

2 Sudargo Gautama,Indonesian Business Law,Pt.Citra Aditya Bakti,Bandung,1995, hlm.76.

3 Mariam Darus Badrulzaman,Aneka Hukum bIsnis, Alumni, Bandung, 1994, hlm.24.
} 


\section{Penambahan klausula Kontrak Tanpa disetujui Salah Satu pihak bertentangan dengan asas Konsensualisme}

Dalam kajian sebelumnya tentang kontrak penulis telah merangkum pada umumnya kontrak berisi serangkaian janji yang dituangkan dalam klausula kontrak, tetapi yang penting harus dipahami janji itu secara tegas merupakan janji yang memiliki akibat hukum dan apabila dilanggar, pemenuhannya dapat dituntut ke pengadilan. Pasal 1313 KUHPerdata mendefinisikan perjanjian sebagai suatu perbuatan yang terjadi antara satu atau dua orang atau lebih mengikatkan dirinya terhadap orang lain, hal ini berarti berkontrak adalah suatu perbuatan hukum (juridical act), yang dibuat dengan formalitas dan diijinkan oleh hukum yang berwenang-dan dibuat bersesuaian dan harus ada ungkapan niat dari satu atau dua pihak secara bersama-sama yang saling bergantung satu sama lain (interdependent), sehingga sejak awal berkontrak para pihak sadar memiliki kedudukan yang sama satu dengan lainnya dan ini dapat dilihat dari sikap batin para pihak.

Sikap batin Para pihak yang jujur akan tercermin dalam substasi dari kontrak sebagaimana dimaksud dalam pasal 1313 KUHPerdata yang memiliki moral dasar untuk saling menguntungkan para pihak yang tercermin dalam itikad baik para pihak. Sikap batin atau keyakinan para pihak yang percaya masing-masing pihak memiliki itikad baik/kejujuran dalam berkontrak tercermin dalam kebebasan para pihak dalam menentukan isi dan muatan hak-hak, kewajiban yang akan dan disepakati, menurut penulis kebebasan ini menduduki posisi strategis dalam hukum berkontrak, dan walaupun kebebasan berkontrak tidak dituangkan menjadi aturan hukum namun mempunyai pengaruh yang sangat kuat dalam hubungan kontraktual para pihak.

Kebebasan berkontrak pada dasarnya merupakan perwujudan dari kehendak bebas yang telah memberi keleluasaan bagi para pihak untuk mengatur sendiri pola hubungan hukumnya dan hal ini tercermin dari substansi Pasal 1338 ayat (I) KUHPerdata yang pada intinya menyatakan semua perjanjian yang dibuat secara sah berlaku sebagai undang-undang bagi mereka yang membuatnya. Pasal 1338 ayat (I) KUHPerdata mengandaikan para pihak dalam berkontrak diperbolehkan membuat perjanjian apa saja dan itu akan mengikat sebagaimana mengikatnya undang-undang. Pembatasan terhadap kebebasan berkontrak hanya dibatasi dengan prinsip ketertiban umum dan kesusilaan. 
Menurut hemat penulis sikap batin para pihak yang tercermin dalam kebebasan berkontrak akan terlihat ketika seseorang pada umumnya mempunyai pilihan bebas untuk mengadakan perjanjian berdasarkan prinsip ketertiban umum dan kesusilaan. Di dalam kebebasan berkontrak terkandung suatu pandangan bahwa orang bebas untuk melakukan atau tidak melakukan perjanjian, bebas dengan siapa ia mengadakan perjanjian, bebas tentang apa yang diperjanjikan dan bebas untuk menetapkan syaratsyarat perjanjian. Namun yang penting untuk diperhatikan bahwa kebebasan berkontrak sebagaimana tersimpul dari ketentuan pasal 1338 (I) BW tidaklah berdiri dengan kesendiriannya. Asas tersebut berada dalam sistem yang utuh dan padu dengan ketentuan lain terkait yaitu asas Konsensualisme

Asas konsensualisme ini menjadi penting ketika dalam praktek dewasa ini, sering kali asas kebebasan berkontrak yang dilandasi sikap batin yang jujur (beritikad baik) tidak dipahami secara utuh bagi para pihak, sehingga banyak memunculkan kesan tendensius hubungan kontraktual yang tidak seimbang dan berat sebelah. Hubungan kontraktual yang tidak seimbang terkadang dihadapkan pada kebebasan berkontrak yang didasarkan pada asumsi dasar yaitu para pihak dalam kontrak memiliki posisi tawar (bargaining position) yang seimbang, tetapi dalam kenyataannya para pihak tidak selalu memiliki tawar yang seimbang, dan untuk itulah menurut penulis asas konsensualitas sangat penting, asas konsensualitas ini nantinya sebagai pedoman dasar untuk memberikan posisi tawar yang seimbang bagi para pihak dan ini tercermin dalam sikap batin para pihak dalam wujud itikad baik.

Sikap batin para pihak yang tercermin dalam Asas konsensualisme mempunyai hubungan yang erat dengan asas kebebasan berkontrak dan asas kekuatan mengikat, pelanggaran terhadap asas-asas ini akan mengakibatkan perjanjian itu tidak sah dan juga tidak mengikat sebagai undang-undang. Asas konsensualisme merupakan "roh" yang tercermin dalam "wujud sikap batin yang beritikad baik" dari suatu kontrak, namun demikian pada situasi tertentu terdapat perjanjian yang tidak mencerminkan wujud kesepakatan yang sesungguhnya sebagaimana dimaksud dalam Pasal 1322- Pasal 1328 B.W.,hal ini disebabkan adanya cacat kehendak (wilsgebreke) atau perjanjian yang pada saat waktu lahirnya mengandung cacat dalam kehendak yang mempengaruhi timbulnya perjanjian.

Asas konsensualisme sebagaimana yang tersimpul dari ketentuan pasal $1320 \mathrm{BW}$ angka (I) yang berkaitan tentang kesepakatan atau toestemming), menyatakan bahwa perjanjian itu telah lahir cukup dengan 
adanya kata sepakat, hendaknya tidak juga diinterpretasikan semata-mata secara gramatikal berhubungan dengan komitmen tanggung jawab hukumnya. Asas konsensualisme menekankan pada " kata sepakat" para pihak yang berawal dari itikad baik para pihak yang berhadapan dalam kontrak yaitu para pihak "sepakat" menjunjung tinggi komitmen dan tanggung jawab dalam hukum, yaitu para pihak memiliki sikap batin percaya dengan itikad baik para pihak, yang berlandaskan pada "satunya kata satunya perbuatan". Sehingga patut ditegaskan yang berhadapan dalam berkontrak itu adalah para "gentleman", maka akan terwujud juga "gentleman agreement" diantara para pihak.

Menurut penulis apabila kata sepakat yang diberikan para pihak tidak berada dalam kerangka saling percaya, dalam arti terdapat cacat kehendak, maka hal ini akan mengancam eksistensi kontrak itu sendiri, hal ini disebabkan pula karena kontrak mempunyai daya berlaku terbatas pada para kontraktan, selain itu dengan kontrak para pihak bermaksud untuk melakukan perbuatan kongkret. Wirjono Prodjodikoro memberikan batasan itikad baik dengan istilah "dengan jujur". Wirjono Projodikoro membagi itikad baik menjadi dua macam, yaitu: Itikad baik pada waktu mulai berlakunya suatu hubungan hukum. Itikad baik di sini biasanya berupa perkiraan atau anggapan seseorang bahwa syarat-syarat yang diperlukan bagi dimulainya hubungan hukum telah terpenuhi. Pasal 1338 (3) B.W. menyatakan bahwa, "perjanjian-perjanjian harus dilaksanakan dengan itikad baik,”. Apa yang dimkasud dengan itikad baik (te goeder trouw; good faith) perundang-undangan tidak memberikan definisi yang tegas dan jelas. Dalam Kamus Besar Bahasa Indonesia, yang di maksud dengan itikad adalah kepercayaan, keyakinan yang teguh, maksud, kemauan (yang baik).

Dalam konteks ini hukum memberikan perlindungan kepada pihak yang beritikad baik, sedang bagi pihak yang beritikad tidak baik (te kwader trouw) harus bertanggung jawab dan menanggung resiko. Itikad baik semacam ini dapat di simak dari ketentuan pasal 1977 (I) BW dan pasal I963 BW, dimana terkait dengan salah satu syarat untuk memperoleh hak milik atas barang melalui daluarsa karena tikad baik ini bersifat subjektif dan statis. Pengertian pengertian itikad baik semacam ini sebagaimana diatur dalam pasal 1338 (3) BW adalah bersifat objektif dan dinamis mengikuti situasi sekitar perbuatan hukumnya. Titik berat itikad baik di sini terletak pada tindakan yang akan dilakukan oleh kedua belah pihak, yaitu tindakan sebagai pelaksanaan sesuatu hal. Secara yuridis feflektif pengertian itikad baik dalam pasal 1338 (3) BW yang mengandung arti para pihak melaksanakan pejanjian dengan itikad baik, merupakan tindakan dinamis dan memiliki arti dalam melaksanakan kontrak kejujuran harus 
berjalan dalam hati sanubari seorang manusia. Para pihak sebagai anggota masyarakat harus jauh dari sifat merugikan pihak lain, atau menggunakan kata secara membabi buta pada saat kedua belah pihak membuat suatu perjanjian. Kedua belah pihak harus selalu memperhatikan hal-hal ini, dan tidak boleh menggunakan kelalaian pihak lain untuk menguntungkan diri pribadi.

Berkaitan dengan aspek kejujuran dalam kesepakatan dan lahirnya perjanjian, Mariam Darus Badrul Zaman mengemukakan beberapa teori mengenai lahirnya perjanjian tersebut yaitu 4:

I. Teori kehendak of will (wilstheorie)

2. Teori kepercayaan (vertrowenstheorie)

Mengajarkan bahwa kesepakatan itu terjadi pada saat pernyataan kehendak dianggap layak diterima oleh pihak yang menawarkan. Menjelaskan bahwa kesepatan terjadi pada saat kehendak pihak penerima dinyatakan, misalkan dengan menulis surat.Teori Pengiriman (verzentheorie) menyatakan kesepakatan terjadi pada saat kehendak yang dinyatakan itu dikirim oleh pihak yang menerima tawaran, dan Teori Pengetahuan (vernemingstheorie), menyatakan pihak yang menawarkan seharusnya sudah mengetahui bahwa tawarannya sudah diterima. Berkait dengan asas konsensualisme prinsip dasar terjadinya kontrak adalah adanya offer (penawaran) dan acceptance (penerimaan) untuk memastikan proses offer dan acceptance ini supaya tidak menimbulkan masalah dimasa yang akan datang maka perlu diperhatikan pihak yang memberikan penawaran dan yang menerima penawaran memiliki kecakapan dan kewenangan untuk melakukan hal tersebut.

Melalui kontrak maka telah lahir suatu akibat hukum yang memiliki dua aspek yaitu hak dan kewajiban yang harus dilaksanakan oleh para subjek hukum yang bersangkutan dalam menepati isi perjanjian, dan untuk mengetahui apakah suatu perjanjian adalah sah atau tidak sah, maka perjanjian tersebut harus diuji empat syarat keabsahan kontrak yang diatur dalam pasal 1320 KUH Perdata.

Adanya kesepakatan kehendak (consensus, Agreement) di harapkan kedua belah pihak harus ada kesesuaian pendapat tentang apa yang diatur oleh kontrak tersebut yang oleh hukum kesepakatan kehendak yang dilandasi kejujuran dan kepercayaan jika tidak terjadinya salah satu unsurunsur sebagai berikut: Paksaan (dwang, duress), Penipuan (bedrog, fraud), Kesilapan (dwaling, mistake) Sebagaimana pasal I32I KUH Perdata 
menegaskan bahwa kata sepakat tidak sah apabila diberikan karena kekhilafan atau diperoleh dengan paksaan atau penipuan.

\section{Pemutusan Kontrak Sepihak Tanpa Persetujuan Merupakan Itikad Tidak baik dalam berkontrak.}

Prinsip dasar lahirnya suatu kontrak adalah adanya offer (penawaran) dan acceptance (penerimaan) untuk memastikan proses offer dan acceptance ini supaya tidak menimbulkan masalah hukum dimasa yang akan datang maka perlu diperhatikan pihak yang memberikan penawaran dan yang menerima penawaran memiliki itikad baik dan kepercayaan dalam membuat kontrak selain tentunya kecakapan dan kewenangan yang dimiliki. Berkaca dari kasus sewa menyewa kendaraan operasional dalam kajian yang penulis jabarkan dalam latar belakang dan rumusan masalah di awal kajian ini maka pemutusan kontrak secara sepihak tanpa persetujan para pihak tentu merupakan bentuk itikad tidak baik apabila pemutusan tersebut di dasarkan pada sikap tidak jujur dari salah satu pihak dan tentunya terkait dengan peraturan-perundangan yang berlaku.

Menjabarkan asumsi hukum di atas maka secara yuridis formal kontrak memiliki 3 (tiga) bentuk berdasarkan cara terjadinya yaitu kontrak konsensual, kontrak formal, dan kontrak riil, sementara perjanjian konsensual adalah suatu perjanjian yang telah terbentuk dengan adanya sepakat. Perjanjian "plus" memiliki arti untuk terpenuhinya syarat sah suatu kontrak selain kata sepakat juga harus ada bentuk perbuatan tertentu,sebagai contoh mengenai pendirian Perseroan Terbatas harus didirikan dengan Akta Pendirian berbahasa Indonesia. Sedangkan perjanjian riil atau kongkrit adalah perjanjian dengan "kata sepakat plus", artinya setelah ada sepakat dan adanya perbuatan nyata misalnya perjanjian pinjam pakai, harus ada serah terima barang.

Mencermati dari kajian yang penulis analisa dari kasus tender pengadaan kendaraan operasional melalui putusan pengadilan Negeri Jakarta selatan yang telah penulis kaji aspek yuridis akademisnya maka suatu kontrak yang telah terbentuk berdasarkan cara terjadinya maka Perjanjian kasus tender pengadaan kendaraan operasional sewa menyewa mobil melalui putusan pengadilan Negeri Jakarta selatan merupakan Perjanjian konsensual, sebagaiman diatur dalam pasal 1548 KUHPerdata, dimana perjanjian tersebut terbentuk sejak terjadinya kata sepakat. kata sepakat tersebut dapat dilakukan secara nyata atau diam-diam. Misalkan sebuah perjanjian sewa-menyewa kendaraan, para pihak telah sepakat tentang isi perjanjian dan bentuk perjanjian, dimana salah satu pihak 
sudah diserahkan kendaraanya namun perjanjian belum ditandatangani, dalam hal ini fakta hukumnya mobil sudah diserahkan berarti menurut hukum sudah terjadi perjanjian dan sudah berlaku;

Menurut hemat penulis bila suatu perjanjian sudah terjadi maka klausul dalam perjanjian itu berlaku seluruhnya dan tidak bisa dipotongpotong. Bila para pihak menyepakati dalam konsep kesepakatan tetapi dalam perjalanan salah satu pihak menambah isi pasal yang memberatkan tanpa diberitahukan pihak lain, maka harus dilihat apakah pihak lawan menyetujui atau tidak, kalau pihak lain setuju tidak masalah, tetapi sebaiknya kalau ternyata ada tambahan klausula perjanjian yang sebelumnya tidak masuk dalam kesepakatan maka harusnya diselesaikan secara kekeluargaan yaitu harus diadakan pembicaraan diantara kedua pihak dengan musyawarah.

Satu masalah hukum yang memiliki ekses yuridis dalam kajian ini adalah ketika kontrak yang telah disepakati dan akan ditandatangani dalam salah satu klausulanya tercantum yuridiksi ketika terjadi sengketa para pihak sepakat akan menyelesaikan melalui arbitrasi, tetapi ketika sepakat secara lisan telah mengikat para pihak, dan ternyata perjanjian secara tertulis disebutkan ada klausula arbitrase tapi perjanjian tidak ditandatangani, maka kontrak tersebut harus dilihat dulu sifatnya apakah bersifat konsensual ataukah riil, bila salah satu pihak membantah klausula arbitrase dan alat bukti hanya perjanjian yang belum ditandatangani dan salah satu pihak tidak sepakati, maka perjanjian itu bersifat konsensual berarti para pihak setuju, dan kalau di sangkal harus dibuktikan dengan tertulis, dan lebih lengkap lagi apabila dibuktikan oleh keterangan saksi.

Fakta hukum yang terungkap dalam persidangan perjanjian yang dibuat para pihak ternyata salah satu pihak ada tambahan klausula maka harus persetujuan pihak lainnya dan bila ada sengketa mengenai hal itu maka yang membuktikan adalah pihak yang paling mudah membuktikan, perjanjian itu dinyatakan berlaku bila sudah ada perbuatan karena perbuatan merupakan salah satu tanda kalau pihak sudah setuju dengan perjanjian itu, sedangkan dalam kasus ini bila mobil sudah diserahkan berarti sudah setuju karena dalam perkara ini dimana inti persetujuan adalah sewa menyewa mobil.

Dalam perjanjian itu salah satu pihak sudah menyerahkan mobil, mobil sudah dinikmati oleh pihak lain, sedangkan pihak lain mencari masalah dengan menambah pasal, maka tambahan perjanjian harus ada kata sepakat. Dan kalau merasa dirugikan pihak yang sudah menyerahkan kendaraan untuk disewakan bisa minta ganti rugi atau dibatalkan perjanjianya. Dalam kasus wanprestasi menyimpukan adanya suatu 
prestasi yang tidak dilaksanakan yang bersumber dari perjanjian yang disepakati, kalau satu perjanjian itu dinyatakan tidak berlaku harus jelas apa alasannya perjanjian itu dinyatakan tidak berlaku.

Menurut pasal $1338 \mathrm{KUHPerdata,} \mathrm{pembatalan} \mathrm{perjanjian} \mathrm{harus} \mathrm{kata}$ sepakat para pihak, kalau satu pihak saja tidak dibetulkan atau dibenarkan secara hukum. Kalaupun dasarnya kuat maka pihak yang akan membatalkan perjanjian dapat mengajukan gugatan.. Pembatalan perjanjian bisa dilakukan hanya terdapat klausul tambahan tapi harus melalui gugatan dan dengan adanya serangkaian peristiwa yang terjadi antara para pihak yang dimulai dari undangan salah satu pihak agar pihak lain mengikuti tender pengadaan kendaraan, yang dilanjutkan dengan penjelasan umum oleh pihak pengadaan tender selaku pelaksana/ pemilik tender dan penunjukkan Penggugat sebagai pemenang tender serta adanya telah dilakukannya serah terima kendaraan sewa dari Penggugat sebagai pemenang tender kepada Tergugat selaku pengguna kendaan.

Apabila para pihak telah terjadi transaksi yaitu serah terima kendaraan yang disewakan dari Pemilik kendaraan kepada selaku pengguna kendaraan. Dengan adanya serah terima barang tersebut maka para pihak secara diam-diam telah setuju dan sepakat untuk saling mengikatkan diri dalam perjanjian sewa menyewanya walaupun dokumen sewa menyewanya sendiri belum ditandatangani oleh para pihak; Perjanjian sewa menyewa mobil termasuk perjanjian konsensual yaitu suatu perjanjian yang telah terbentuk dengan adanya sepakat yang terbentuk sejak adanya kata sepakat.

Berdasarkan analisa di atas antara Para pihak telah terjalin suatu hubungan hukum perikatan dalam bentuk sewa kendaraan. Sehingga beralasan hukum bila antara Para pihak dinyatakan telah terjadi perikatan sewa menyewa kendaraan operasional lapangan. Fakta dilapangan antara Para Pihak telah dibuat draft perjanjian Jasa Penyewaan Kendaraan yang pada pokoknya berisi perjanjian sewa kendaraan dari Para pihak untuk dioperasikan oleh salah satu pihak. Fakta salah satu pihak yang mengadakan tender dalam menjelaskan draft awal perjanjian sewa kendaraan kepada para peserta tender termasuk Pihak pemenang tender, tidak pernah menjelaskan tentang adanya tambahan klausula dalam kontrak.

Suatu perjanjian yang tidak pernah diperjanjikan tidak mengikat para pihak, dan bila mana ada suatu tambahan klausul dalam perjanjian maka klausul tambahan tersebut haruslah mendapat persetujuan dari para pihak, tanpa adanya persetujuan maka tambahan klausul perjanjian menjadi tidak sah, apalagi penambahan klausula tersebut yang mana 
sebelumya pada draft awal perjanjian tersebut belum dicantumkan; Fakta yang terungkap Pihak yang melakukan tender telah memberikan tambahan klausul pada surat Perjanjian yang mana pada awal penjelasan lelang tidak pernah dijelaskan. Atas tambahan tersebut Pemenang tender menyatakan keberatan dan tidak bersedia mendatangani surat perjanjian serta mengembalikan kepada Pihak yang melakukan tender. Dengan adanya fakta hukum bahwa Pihak pemenang tender tidak pernah menyetujui penambahan klausul yang dilakukan oleh Tergugat maka dengan mengacu asas Konsesnsualisme sebagaimana tercantum dalam pasal ${ }_{1338}$ KUHPerdata yang menyatakan bahwa penambahan klausul yang tidak disertai persetujuan oleh para pihak maka penambahan tersebut menjadi tidak sah, maka beralasan bila penambahan yang dilakukan oleh Pihak yang membatalkan sepihak dinyatakan tidak beralasan hukum.

Fakta yang terungkap dalam persidangan ternyata Pemenang Tender telah dinyatakan sebagai pemenang tender lelang oleh Penyelenggara Tender dan pelelangan telah dilaksanakan sesuai dengan tata cara dan ketentuan yang berlaku. Selain itu ternyata Pemenang lelang telah melaksanakan kewajibannya yaitu menyediakan kendaraan sesuai dengan permintaan Penyelenggara Lelang dan mengasuransikan seluruh kendaraan yang diserahkan untuk dioperasiakan oleh Penyelenggara Lelang.

\section{KESIMPULAN}

Asas konsensualisme dalam berkontrak penting ketika asas kebebasan berkontrak yang dilandasi sikap batin yang jujur (beritikad baik) tidak dipahami secara utuh bagi para pihak, sehingga banyak memunculkan kesan tendensius hubungan kontraktual yang tidak seimbang dan berat sebelah. Hubungan kontraktual yang tidak seimbang akan dihadapkan pada kebebasan berkontrak yang didasarkan pada asumsi dasar yaitu para pihak dalam kontrak memiliki posisi tawar (bargaining position) yang seimbang, tetapi dalam kenyataannya para pihak tidak selalu memiliki tawar yang seimbang, dan untuk itulah asas konsensualitas sangat penting, asas konsensualitas ini nantinya sebagai pedoman dasar untuk memberikan posisi tawar yang seimbang bagi para pihak dan ini tercermin dalam sikap batin para pihak dalam wujud itikad baik. Ini Sikap batin para pihak yang tercermin dalam Asas konsensualisme mempunyai hubungan yang erat dengan asas kebebasan berkontrak dan asas kekuatan mengikat yang terdapat di dalam pasal 1338 (I) BW. 
Asas konsensualisme merupakan "roh" yang tercermin dalam "wujud sikap batin yang beritikad baik" dari suatu perjanjian. Hal ini tersimpul dari kesepakatan para pihak, namun demikian pada situasi tertentu terdapat perjanjian yang tidak mencerminkan wujud kesepakatan yang sesungguhnya. Hal ini disebabkan adanya cacat kehendak (wilsgebreke) yang mempengaruhi timbulnya perjanjian. Makna itikad baik dalam pasal 1338 (3) BW adalah perbuatan dinamis dalam berkontrak artinya dalam melaksanakan perbuatan ini kejujuran harus berjalan dalam hati sanubari seorang manusia. Kedua belah pihak harus selalu memperhatikan kejujuran, dan tidak boleh menggunakan kelalaian pihak lain untuk menguntungkan diri pribadi. Mencermati dari kajian kasus tender pengadaan kendaraan operasional melalui putusan pengadilan Negeri Jakarta selatan yang telah penulis kaji aspek yuridis akademisnya maka suatu kontrak yang telah terbentuk berdasarkan cara terjadinya maka Perjanjian kasus tender pengadaan kendaraan operasional sewa menyewa mobil melalui putusan pengadilan Negeri Jakarta selatan merupakan Perjanjian konsensual, sebagaiman diatur dalam pasal 1548 KUHPerdata, dimana perjanjian tersebut terbentuk sejak terjadinya kata sepakat.

\section{SARAN}

Berkontrak sebagai awal kerjasama yang berlandaskan kejujuran dan itikad baik, maka pada saat kontrak dibuat harus ada ungkapan niat dari keduabelah pihak secara bersama-sama yang saling bergantung satu sama lain (interdependant) dan sepakat bersama (mutual consent) dengan akhir kata sepakat yang berkesesuaian kehendak para pihak di dalam perjanjian berupa niat baik para pihak dengan persetujuan bersama untuk menciptakan adanya akibat hukum yang akan dijalankan bersama. Penambahan klausul kontrak tanpa disetujui oleh salah satu pihak yang bertentangan dengan asas konsensualitas bisa dihindari apabila sikap batin yang jujur dan beritikad baik dipahami penuh dan utuh oleh masingmasing pihak yang bersepakat.

Pemutusan kontrak sepihak tanpa persetujuan merupakan itikad tidak baik dari salah satu pihak dan sangat merugikan pihak lainnya, untuk itu menurut penulis bila suatu perjanjian sudah terjadi maka klausul dalam perjanjian itu berlaku seluruhnya dan tidak bisa dipotong-potong. Dan apabila dalam perjalanan salah satu pihak menambah isi pasal yang memberatkan tanpa memberitahukan pihak lain maka harus dilihat apakah pihak lawan menyetujui atau tidak yang tentunya itu bisa diselesaikan secara kekeluargaan dengan diadakannya pembicaraan diantara keduabelah 
pihak secara musyawarah mufakat.

\section{DAFTAR PUSTAKA}

Badrulzaman, Mariam Darus, BW Buku III, Hukum Perikatan Dengan Penjelasan, Alumni, Bandung, 1996 , Aneka Hukum Bisnis, Alumni, Bandung, 1994

Bahsan, M, Hukum Jaminan dan Jaminan Kredit Perbankan Indonesia, Radja Grafindo Persada, Jakarta, 2007

Djumhana, Muhamad, Hukum Perbankan di Indonesia, Citra Aditya Bakti, Bandung, 2006

Hernoko, Agus Yudha, Hukum Perjanjian Asas Proporsionalitas dalam Kontrak Komersial, Kencana Media Prenada Group, Cetakan 2, Jakarta, 20II

Mulyadi, Kartini dan Gunawan Wijaya, Seri Hukum Perikatan, Perikatan Yang Lahir Dari Perjanjian, Raja Grafindo Persada, Jakarta, 2002

Simamora, Yohanes Sogar, Hukum Perjanjian, Prinsip Hukum Kontrak Pengadaan Barang dan Jasa Oleh Pemerintah, LaksBank Presindo, Jogjakarta, 2009

Subekti, Hukum Perjanjian, Cet. 19, Intermasa, Jakarta, 2002

Subekti dan Tjitrosudibjo, Kitab Undang-undang Hukum Perdata, Pradnya Paramita, Jakarta, 1980, Lembaran Negara RI Tahun 1974 Nomor I

Yudha Hernoko Agus, hukum Perjanjian, Prenadamedia Group, Jakarta,2010.

Fuady Munir, Teori-Teori Besar dalam Hukum, Prenadamedia Group, Jakarta, 2013

J. Satrio, Hukum Perikatan, Perikatan yang lahir dari Perjanjian, Bandung, 1995

Sudargo Gautama, Indonesian Business Law, Pt.Citra Aditya Bakti, Bandung.1995.

Mariam Darus Badrulzaman, Aneka Hukum bisnis, Alumni, Bandung, 1994. 
